\title{
IZAZOVI STARENJA OSOBA S INTELEKTUALNIM TEŠKOĆAMA
}

\author{
ANA WAGNER JAKAB ${ }^{1}$, ZRINKA DUMANČIĆ ${ }^{2}$, KATARINA SAČER ${ }^{3}$ \\ ${ }^{1}$ Edukacijsko-rehabilitacijski fakultet, Odsjek za Inkluzivnu edukaciju i rehabilitaciju, Sveučilišta u Zagrebu, \\ ana.wagner-jakab@erf.hr, ${ }^{2}$ Centar inkluzivne podrške - Idem, Zagreb
}

Primljeno: 23.3.2016.

Pregledni rad

Prihvaćeno: 29.8.2016.

UDK: 613.98-056.36

Sažetak: U ovom radu bit će prikazani neki izazovi starenja osoba s intelektualnim teškoćama na koje ukazuje međunarodna znanstvena i stručna zajednica zadnjih dvadesetak godina. U Hrvatskoj se o ovoj temi nedovoljno istraživalo i pisalo, iako su u velikoj mjeri prisutni problemi osiguravanja adekvatne skrbi za stariju populaciju osoba s intelektualnim teškoćama.

Populacija starijih tipičnih osoba sve je brojnija u razvijenim zemljama, a životni vijek osoba s invaliditetom u razvijenim zemljama produljuje se paralelno sa životnim vijekom osoba tipičnog razvoja. Iako su neki procesi tijekom starenja slični za populaciju osoba sa i bez intelektualnih teškoća, ipak su prisutni i neki specifični povećani rizici kod osoba s teškoćama, o kojima je potrebno voditi računa prilikom planiranja podrške. Izazovi za društvo su osigurati adekvatnu skrb o osobama s intelektualnim teškoćama koje stare, a pritom voditi računa o specifičnim potrebama ovih osoba, te u tom smjeru razvijati specifične politike $i$ implementaciju strategija.

Ključne riječi : starenje, osobe s intelektualnim teškoćama, servisi podrške.

\section{UVOD}

„Starenje kao proces trošenja koji ima vijek trajanja započinje već s postankom“ (AmbrosiRandić, Plavšić, 2008, str.13). Usprkos ljudskoj želji da se ovaj proces uspori, ili još bolje, potpuno zaustavi, starenje je neizbježno i nezaustavljivo. Kvaliteta starenja, pa time i kvaliteta života, jedinstvena je i različita od osobe do osobe, kao i konteksta u kojem živi.

Ljudi oduvijek pokušavaju shvatiti uzroke i tijek starenja - te nezaobilazne pojave ljudskog života i prirode. Otkako postoje ljudski zapisi nailazi se na podatke koji pokazuju da je starenje bilo značajna tema razmišljanja i proučavanja ljudi (Despot Lučanin, 2003; Sačer, 2014). No, o starosti i starenju osoba s intelektualnim i višestrukim teškoćama vrlo je malo provedenih istraživanja i objavljenih radova (Jenkins, 2012). Starije osobe s intelektualnim teškoćama u opasnosti su od dvostruke diskriminacije. Ove su osobe općenito suočene s brojnim socijalnim, strukturnim i ekonomskim preprekama koje im uskraćuju puna građanska prava i jednake mogućnosti. Diskriminacija može nastati i iz predrasuda o starenju unutar društva, kojima se pogoršava ionako marginaliziran položaj starijih osoba s intelektualnim teškoćama (Murphy i sur. 2007, Sačer, 2014).

Obzirom da je starenje proces koji može imati vrlo različite kvalitete, koje nisu uvijek povezane sa samom kronološkom dobi a utječu na kvalitetu života čovjeka, važno je u nastavku osvrnuti se na razliku između pojmova starost i starenje i na njihove osnovne značajke.

\section{STARENJE I STAROST}

Svako živo biće stari. Od rođenja, kako se razvijamo, tako i starimo. Birren i Birren (1990 prema Despot Lučanin, 2003) opisuju starenje kao dopunu razvoja, u smislu njihove uske povezanosti. Razvoj podrazumijeva progresivne promjene koje se pojavljuju u predvidljivim obrascima kao rezultat interakcije između bioloških i okolinskih čimbenika. Razvoj ne završava u nekom određenom trenutku, pa tako organizam može i nakon dostizanja fizičke zrelosti nastaviti s povećanjem složenosti i istovremene diferencijacije. To znači da 
se razvoj i starenje događaju istovremeno (Despot Lučanin, 2003).

Starost je posljednje razvojno razdoblje u životnom vijeku pojedinca koje se može definirati prema kronološkoj dobi (npr. nakon 65. godine života), prema socijalnim ulogama ili statusu (npr. nakon umirovljenja), ili pak prema funkcionalnom statusu (npr. nakon određenog stupnja opadanja sposobnosti). Prema definiciji Svjetske zdravstvene organizacije, starije su osobe one u dobi između 60 i 75 godina; stare su osobe u dobi između 76 i 90 godina, a veoma stare osobe su osobe iznad 90 godina (Brajković, 2010).

U razvojnoj psihologiji ovo se razdoblje često označava kao kasna odrasla dob. Određenja prema kronološkoj dobi uobičajeno navode donju granicu od 60 ili 65 godina za ovu dob. Ovo je dob promjene socijalnih uloga (npr. umirovljenje), a u pogledu funkcionalnog statusa postoje velike individualne razlike. Uobičajeno je da se uz ovo razdoblje ljudskog života povezuje smanjena tjelesna snaga i slabije zdravlje. Međutim, treba imati na umu velike individualne razlike među osobama u kasnoj odrasloj dobi. Ove se razlike mogu uočiti u stupnju zadovoljstva životom, kvaliteti života, aktivnosti, socijalnoj uključenosti i razini doživljenoga stresa (Galić i sur., 2013).

Starenje je proces tijekom kojega se događaju promjene u funkciji dobi. Kada govorimo o starenju, nužno je razlikovati primarno i sekundarno starenje. Primarno starenje poistovjećuje se $\mathrm{s}$ fiziološkim starenjem, a odnosi se na normalne, fiziološke procese koji su posljedica sazrijevanja i protoka vremena (npr. menopauza kod žena). Sekundarno starenje odnosi se na patološke promjene koje su posljedica vanjskih čimbenika, a uključuju bolest, okolinske utjecaje i ponašanja (npr. utjecaj buke na slabljenje sluha) (Despot Lučanin, 2003; Lepan i Leutar, 2012).

Razlikujemo tri osnovna vida starenja (Brajković, 2010):

- biološko, odnosno promjene, usporavanje i opadanje u funkcijama organizma s vremenom;

- psihološko, odnosno promjene u psihičkim funkcijama i prilagodba ličnosti na starenje;

- socijalno, odnosno promjene u odnosu pojedinca koji stari i društva u kojem živi.
Starenjem se događaju promjene koje su neminovne, no način na koji će ih ljudi kvalitetno proživjeti različit je i ovisi o individualnim čimbenicima pojedinca, ali u velikoj mjeri i o vanjskim odnosno okolinskim čimbenicima. Obzirom na to, starenje može biti "uobičajeno/normalno" i "uspješno" (Despot Lučanin, 2003). Obzirom da je cilj svakog čovjeka postići "uspješno" starenje, za koje nam osim vlastitih resursa trebaju i vanjski resursi, slijedi kratki opis tog pojma.

\section{USPJEŠNO STARENJE}

Dobro starjeti podrazumijeva sposobnost suočavanja s vlastitim unutarnjim, fiziološkim promjenama, kao i s vanjskim, socijalnim promjenama. Cilj je postići sklad među njima (Cohen-Sachs, 1993; Despot Lučanin, 2003).

U uobičajenom starenju okolinski čimbenici potiču procese primarnog, fiziološkog starenja. U uspješnom starenju okolinski čimbenici imaju neutralan ili pozitivan učinak. Drugim riječima, starenje se više ne smatra nepromjenjivim već promjenjivim procesom, zahvaljujući različitim intervencijama - medicinskim, psihološkim i okolinskim. Iako je nemoguće zaustaviti otkucavanje biološkog sata, ono se može usporiti i može mu se promijeniti ton. Budući da granice promjenjivosti nisu poznate, novo viđenje starenja budi nadu u zdravo i produktivno razdoblje pri kraju ljudskog života.

Uspješno starenje ne započinje sa šezdeset i pet godina. Ono je utemeljeno na načinu života kojim se održava zdravo tijelo i zdrav um - navikama pravilne prehrane i tjelovježbe, uključivanjem u zanimljive aktivnosti koje predstavljaju izazov za um. Usvajanje i razvijanje takvih navika povezano je s obrazovanjem osobe te sa stavovima i podrškom obitelji i prijatelja koji cijene zdrav i produktivan život. Optimalno odnosno uspješno starenje također se može potaknuti usvajanjem tehnika za ublažavanje stresa i djelotvorno suočavanje s promjenama, kao i usvajanjem slobodnih aktivnosti koje ne zahtijevaju veliku tjelesnu snagu i izdržljivost. Osim toga, važno je održati sustav socijalne podrške te novim odnosima s drugim ljudima nadoknaditi one izgubljene.

Uspješno starenje može se promatrati kao nadrastanje vlastitog životnog iskustva. Nije bitno 
koliko je netko star, već kako je star. Osoba koja uspješno stari jest ona koja je uspjela pronaći nove aktivnosti kojima zamjenjuje aktivnosti koje je prerasla ili koje je bila prisiljena napustiti. Prema Despot Lučanin (2003), osoba koja uspješno stari osoba je koja je odlučila postati aktivna - tjelesno, intelektualno, emocionalno i socijalno. To podrazumijeva:

- usvajanje novih tjelesnih i psihičkih navika;

- održavanje socijalnih vještina, ali i spoznaju pravog užitka samoće;

- razvijanje filozofije koja daje smisao cjelokupnom životu;

- vrednovanje svih ljudi;

- poticanje vlastitih potencijala;

- traženje ispunjenja u cijelom životu te

- uživanje u svakom trenutku života (str.211).

Opisujući neke osobitosti starenja kao i naglašavajući mogućnost uspješnog starenja, možemo se zapitati kako stare osobe s intelektualnim teškoćama, postoje li razlike u starenju opće populacije i njih, te mogu li osobe s intelektualnim teškoćama uspješno stariti i kako im to omogućiti.

\section{STARENJE OSOBA S INTELEKTUALNIM TEŠKOĆAMA}

Populacija starijih osoba bez teškoća u razvijenim zemljama je u porastu, što potvrđuje podatak da se u posljednjih 160 godina ljudski vijek produljio za 40 godina te se i dalje produljuje za prosječno tri mjeseca godišnje, dok se natalitet smanjuje (Lepan i Leutar, 2012). Sukladno tome, dostignuća na području znanosti - medicine, javnog zdravstva, tehnologije, obrazovanja itd., doprinose duljem životnom vijeku i osoba s intelektualnim teškoćama (World Health Organization, 2001; International Association for the Scientific Study of Intellectual Disabilities 2002; Jenkins, 2012). Procjenjuje se da diljem svijeta živi oko 60 milijuna osoba s intelektualnim teškoćama, što ih čini jednom od najvećih skupina osoba s invaliditetom (International Association for the Scientific Study od Intellectual Disabilities, 2002).

Iako se za odrasle osobe s intelektualnim teškoćama smatralo da imaju prirođeno skraćeni životni vijek (uglavnom zbog nedostatka medicinske njege, rehabilitacije i loših životnih uvjeta), danas većina ovih osoba koje žive u razvijenim zemljama dožive svoju starost. Činjenica koju navodi jedna od eminentnih organizacija koja okuplja istraživače koji se bave temom intelektualnih teškoća International Association for the Scientific Study of Intellectual Disabilities (2002), jest kako će se životni vijek osoba s invaliditetom u razvijenim zemljama produljivati paralelno sa životnim vijekom osoba u općoj populaciji.

Neki autori navode da općenito vlada mišljenje kako osobe s intelektualnim teškoćama podliježu istom fizičkom propadanju tijekom starenja kao i opća populacija starijih osoba, dok drugi autori (Holland 2000; O Rourke i sur.; 2004; Janicki i sur. 2002; Jenkins, 2012) utvrđuju da, iako možemo govoriti o sličnom stupnjevanju potreba za zdravstvenom i socijalnom skrbi, ipak postoje neke razlike između ovih dviju populacija, a koje značajno utječu na kvalitetu života, zdravlje i dobrobit starijih osoba s intelektualnim teškoćama.

Pregledom literature od 1999. do 2010. uočeni su određeni povišeni zdravstveni rizici kod starijih osoba s intelektualnim teškoćama (Jenkins, 2012). Neki od njih su kardiovaskularne bolesti, hipertenzija, gastrointestinalna stanja (heliobacter pylori, refluksi i konstipacije), osteoporoza, oralni problemi (karijesi, gingivitis) kao i pretilost. Isto tako zabilježeni su rizični faktori povezani sa životnim stilom kao što je loša ishrana i manjak fizičke aktivnosti.

Nalazi pokazuju da oko $40 \%$ osoba s intelektualnim teškoćama, naspram $25 \%$ osoba iz opće populacije, razvijaju stanja kao što su depresija, anksioznost, poremećaji hranjenja, kompulzivni poremećaj i psihoze, koje zahtijevaju raspoloživost različitih vrsta tretmana (Whitaker i Read; 2006, Došen, 2011; Brown i sur. 2011). Takva stanja postaju dodatno komplicirana kada se povežu s promjenama koje nastaju tijekom starenja. To su, primjerice, neurološke promjene, senzoričke teškoće, prisutnost boli, doživljaj gubitka, nisko samopouzdanje, fizičko propadanje, smanjivanje socijalnih kontakata i mreža kao i smanjivanje aktivnosti (Jenkins, 2012).

Hubert i Hollins (2000) izvještavaju da povećan rizik od psihijatrijskih problema starijih osoba s intelektualnim teškoćama uključuje pojavu 
demencije, anksioznosti, depresije, afektivnih stanja i deluzija. Jenkins (2012) te Coyle i suradnici (2014) naglašavaju da je zamijećena povezanost Downovog sindroma i Alzheimerove bolesti, a McCarron (1999; prema Jenkins, 2012) navodi da gotovo sve osobe s Downovim sindromom starije od 35 godina imaju neuropatološke promjene karakteristične za Alzheimerovu bolest. Nadalje, pojedine skupine osoba s intelektualnim teškoćama pod visokim su rizikom razvoja demencije (Janicki, 2011). Uz to, mnogi simptomi bolesti prolaze neprimjećeno ili se prepoznaju kasnije, pa su zdravstvene potrebe osoba s intelektualnim teškoćama zasigurno puno veće nego što se to čini (Jenkins, 2012).

Nalazi iz literature i praktična iskustva, kako u svijetu tako i u nas, pokazuju da su tretmani i intervencije kod osoba s intelektualnim teškoćama i narušenim mentalnim zdravljem nedovoljno primjereni i učinkoviti (Brown i sur. 2011), što i ne čudi ako uzmemo u obzir da i za opću populaciju starijih osoba postoje ograničenja u dostupnosti terapija, u smislu psihoterapije i savjetovanja (Schaie i Willis, 2000; Glicken, 2009).

Općenito govoreći, vrlo se često neki simptomi ili specifična stanja osoba s intelektualnim teškoćama tumače upravo intelektualnim teškoćama, iako su ponekad uobičajena i za opću populaciju, ili su pak specifična za funkcioniranje osoba s intelektualnim teškoćama. U svakom slučaju, opća populacija tijekom života kognitivno se i emocionalno priprema za promjene i određene gubitke koje donosi starenje, dok su osobe s intelektualnim teškoćama često nepripremljene na to i teže ih prihvaćaju. Zbog prirode samih intelektualnih teškoća ove su osobe ranjiva skupina, koja na temeljna ograničenja u kognitivnom, emocionalnom i socijalnom funkcioniranju s vremenom razvijaju i dodatna ograničenja, koja zahtijevaju specifične, planirane sustave podrške, usmjerene kako samim osobama, tako i njihovim obiteljima. Upravo zbog toga društvo je dužno osigurati temeljna prava osobama s intelektualnim teškoćama kao što su pravo na na zdravstvenu skrb, adekvatnu prehranu i stanovanje, društvene interakcije, zapošljavanje i aktivnosti slobodnog vremena karakteristične za stariju dob, te materijalnu sigurnost i blagostanje.

Socijalna podrška starijim osobama igra važnu ulogu u smanjivanju stresa što vodi i boljem tjelesnom zdravlju i psihičkoj dobrobiti pa tako pove- ćava i mogućnosti za dulji život. Socijalna podrška može smanjivati vjerojatnost stresnog događaja, modificirati percepciju stresora i umanjiti stresni potencijal, utjecati na strategije suočavanja i izravno utjecati na razinu prilagodbe.

\section{SUSTAVI PODRŠKE OSOBAMA S INTELEKTUALNIM TEŠKOĆAMA U PROCESU STARENJA}

Osnovni socijalni čimbenik koji je značajan prediktor kvalitete starenja jest prisustvo i podrška drugih ljudi (Despot Lučanin, 2003) što je, osim potrebe starijih ljudi da budu korisni svojoj okolini (Brajković, 2010), ključni faktor ljudskog osjećaja dobrobiti u svakodnevnom životu (Bratković, 2002). Osobama $\mathrm{s}$ intelektualnim teškoćama individualnu podršku uglavnom pruža obitelj, značajne druge osobe, osoblje i službe podrške, a potrebe za podrškom u različitim životnim područjima mogu se mijenjati tijekom života (Bratković, 2002). Također je važno da podrška bude pružena izravno u osobnom životnom okružju osobe ( Bratković, 2002). Izvori podrške imaju važnu ulogu i u osjećaju opterećenosti. Osobe koje imaju veću podršku, imaju manji osjećaj tereta.

Američka asocijacija za mentalnu retardaciju (AAMR) definirala je matricu planiranja podrške (Schalock, 1997; prema Bratković, 2002) prema kojoj podrška osobi može biti pružena unutar osam dimenzija kvalitete življenja.

Prema matrici definiranja podrške (Schalock, 1997; prema Bratković, 2002) podrška može osobi biti pružena unutar osam dimenzija kvalitete življenja. To su: emocionalno blagostanje, međuljudski odnosi, materijalno blagostanje, osobni razvoj, fizičko blagostanje, samoodređenje, socijalno uključivanje i prava. U primjeni opisanog suvremenog ,obrasca podrške" važno je da podrška treba biti osigurana u normalnom, integriranom okružju; u pružanju podrške primarno trebaju sudjelovati osobe koje žive, rade ili provode slobodno vrijeme unutar tih okružja; podrška treba biti individualno usmjerena; ona se može mijenjati i varirati od podrške tijekom cijelog života, do promjenjivih potreba u različitim fazama života, te nikada ne bi smjela biti naglo prekinuta.

Bigby (2010) je uspoređivala politike i strategije servisa podrške starim osobama s intelektualnim teškoćama u pet zemalja s jakom i stabilnom 
ekonomijom i socijalnom politikom: Australija, Kanada, Ujedinjeno Kraljevstvo, Irska i Sjedinjene Američke Države. Autorica ističe da su ove zemlje još od 80-tih godina prošlog stoljeća imale vrlo jaku politiku usmjerenu na podržavanje, odnosno omogućavanje starim i starijim osobama da stare kod kuće ili u poznatoj okolini, u manjim stambenim zajednicama u njihovom susjedstvu, takozvanu politiku "aging in place", kojom se izbjegava institucionalizacija i segregacija, te osobe ostaju u poznatoj okolini, okružene obitelji, prijateljima, susjedima i predmetima u osobnom vlasništvu.

Prijatelji i susjedi važni su kao izvor socijalne podrške jer često mogu brže od obitelji priskočiti u pomoć starijoj osobi s obzirom na prostornu blizinu (susjedi) i s obzirom na učestalost susreta (prijate1ji). Unatoč gubitaka mnogih prijatelja iz mladosti, u starosti se mogu steći novi prijatelji, što je izvor zadovoljstva kojem svakako doprinosi i činjenica da je izbor prijatelja naš slobodan izbor, za razliku od članova obitelji koje ne biramo voljno. Vrlo stari ljudi češće znaju imati znatno mlađe prijatelje, često stoga jer su mnogi njihovi vršnjaci umrli.

"Aging in place" pristup odnosi se i na opću populaciju i na populaciju osoba s teškoćama, u ovom slučaju osoba intelektualnim teškoćama. Prepoznato je da servisi podrške starijoj općoj populaciji nisu dostatni za stariju populaciju osoba s intelektualnim teškoćama, te je ovoj populaciji potrebno osigurati i specifične oblike podrške (Bigby, 2010).

Socijalnu podršku osobe s intelektualnim teškoćama dobivaju i kroz dnevne centre, za koje same ove osobe izjavljuju da su im važne jer im pružaju osjećaj da su aktivne, neovisne i da imaju mrežu prijatelja (Zucman, 2000 ; Judge i sur. 2010.). Da bi se stekao potpuniji uvid u zadovoljstvo i sreću osoba s teškoćama, kao i njihove potrebe i probleme, potrebno je da same ove osobe progovore o svojim iskustvima i doživljajima ( Walmsley i Johnson, 2003; Bratković i Rozman, 2006; Murphy i sur., 2007), međutim, takva su participativna ispitivanja rijetka (O Rourke i sur., 2004).

Rezultati nekih ispitivanja pokazuju da starije osobe, kako one koje žive u gradovima, tako i one koje žive u selima, izvještavaju o većem zadovoljstvu životom kada u susjedstvu stanuje više starijih stanovnika, jer im je dostupno društvo osoba sličnih po dobi (Galić i Tomasović Mrčela, 2013) Prisutnost obitelji nije nužna, sve dok susjedi i bliski prijatelji pružaju socijalnu podršku. U usporedbi sa starijima u urbanim područjima, stare osobe koje žive u tihim susjedstvima malih i srednje velikih zajednica zadovoljnije su životom ( O Rourke i sur. 2004; Galić i Tomasović Mrčela 2013). Nadalje (ibid.), osobe koje žive u seoskim sredinama iskazale su veće zadovoljstvo odnosima i prijateljstvima od osoba koje žive u urbanim stambenim zajednicama. Međutim, nedostatak ruralnih sredina leži u nedostupnosti specifičnih servisa podrške osobama $\mathrm{s}$ intelektualnim teškoćama, naročito ako se radi o dislociranim mjestima (Wark i sur. 2013).

Broj osoba s intelektualnim teškoćama koje žive u obiteljima opada s porastom njihove kronološke dobi (Bigby, 2010). Kako bi osobe s intelektualnim teškoćama mogle starjeti u svojoj poznatoj okolini, potrebno je osigurati im odgovarajuće službe podrške: pomoć u kući, stanovanje uz podršku ili pak stanovanje u malim stambenim zajednicama, čime se izbjegava neprimjereni smještaj u institucijama.

Važno je naglasiti da su obitelji starijih osoba s intelektualnim teškoćama često "stare obitelji", odnosno roditelji koji o njima skrbe i sami su stari ili vrlo stari. Osim roditelja, mogući skrbnici su sestre i braća ili rođaci, no oni vrlo često imaju svoju obitelj, posao, obveze i većinu vremena u svojoj produktivnoj fazi života provode izvan kuće, što otežava ili onemogućava njihovu skrb za člana obitelji s intelektualnim teškoćama (Coyle i sur. 2014).

U situacijama kada je postignuto optimalno rješenje te osobe $s$ intelektualnim teškoćama žive $u$ svojoj najbližoj okolini, uz dodatne, njima prilagođene službe podrške, događa se da se nakon smrti roditelja, ili kada se opće stanje roditelja pogorša, osobu s intelektualnim teškoćama odmah premješta u dom za starije i nemoćne. Ovakvo rješenje rezultat je nedostatka drugih alternativa i nije najbolje rješenje za osobu (Bigby i sur. 2008 ; Bigby, 2010).

Nalazi studija više zemalja (Australije, Irske i Ujedinjenog Kraljevstva) ukazuju na zabrinjavajući podatak da velik dio osoblja stambenih zajednica smatra da je u nekom trenutku nezaobilazno premještanje starijih osoba s intelektualnim teškoćama na institucionalnu skrb za starije i nemoćne. Istovremeno, nalazi ukazuju da u institucionalnoj 
skrbi nisu adekvatno zadovoljene potrebe osoba s intelektualnim teškoćama tijekom starenja, jer ove osobe ne odgovaraju profilu ostalih korisnika - vrlo često one su mlađe dobi, rjeđe imaju demenciju, vremenski duže od ostalih tipičnih korisnika ostaju na smještaju. Nedostatak jasnih politika i strategija koje omogućavaju rješenja alternativna institucionalnoj skrbi predstavljaju veliku prijetnju kvalitetnoj sustavnoj podršci starijih osoba s intelektualnim teškoćama (Bigby, 2010).

Nadalje, potrebno je pomno planirati kada i iz kojih je razloga povoljan trenutak za smještavanje starije osobe s intelektualnim teškoćama na institucionalnu skrb. Istraživanja pokazuju da se osobe s intelektualnim teškoćama starije dobi često prerano smještavaju u institucije, ponekad čak u njihovim srednjim godinama, obično jer su u to vrijeme njihovi roditelji već ostarjeli. Isto tako, taj premještaj potrebno je pažljivo planirati i provoditi kroz određeni vremenski period. Osobe s intelektualnim teškoćama često prvo proživljavaju premještaj iz obiteljskog doma u stambenu zajednicu, da bi onda bile premještene na institucionalnu skrb odnosno u stacionar. Pritom je nužno voditi računa o tome koliko priroda samih teškoća ovih osoba utječe na njihov adaptivni potencijal, uz činjenicu da se i ove osobe sve teže prilagođavaju promjenama s porastom dobi. Novi ljudi, nova i nepoznata sredina, nove rutine, osobe čine anksioznima i prestrašenima. Svjedoci smo obrnutog primjera u Hrvatskoj, gdje su pojedine osobe tijekom procesa deinstitucionalizacije teško prihvaćale premještanje u stambene zajednice, osjećajući anksioznost zbog promjene, jer se proces transfera nije pravovremeno i dobro planirao. Vrlo je važno je uključiti osobe $\mathrm{s}$ intelektualnim teškoćama u proces donošenja odluke o vlastitoj budućnosti (Bigby i sur. 2011).

Podrška starenju osobama s intelektualnim teškoćama često se bazira na kapacitetima i resursima unutar pojedinih vladinih i nevladinih organizacija, obitelji osoba s teškoćama kao i lokalne zajednice (Bigby i sur. 2008), što, međutim, nije dovoljno i to pitanje trebalo bi rješavati sustavno, dobro promišljenim nacionalnim politikama i legislativom.

Čak i u najrazvijenijim zemljama još uvijek nedostaju jaki, kvalitetni i dobro osmišljeni okviri politika, kao temelji strategija i principa koji će osobama $\mathrm{s}$ intelektualnim teškoćama omogućiti starenje koje neće biti prijetnja njihovoj dobrobiti (Bigby, 2010). S obzirom na opisane izazove i teškoće u zemljama koje nama služe kao mogući model razvoja, možemo se zapitati kakva je situacija u našoj zemlji.

\section{NEKI IZAZOVI STARENJA OSOBA S INTELEKTUALNIM TEŠKOĆAMA I NJIHOVIH OBITELJI U HRVATSKOJ}

U Hrvatskoj se potiče socijalno uključivanje i deinstitucionalizacija, no pritom se posebno ne naglašavaju teškoće populacije starijih i starih osoba s invaliditetom, u čiju skupinu pripadaju i osobe $\mathrm{s}$ intelektualnim teškoćama.

Prve inicijative deinstitucionalne skrbi o osobama s intelektualnim teškoćama u Hrvatskoj pokrenule su nevladine organizacije (primjerice Udruga za promicanje inkluzije).

Na razini Vlade Republike Hrvatske inicijativa je pokrenuta u okviru reforme socijalne politike kroz „Plan deinstitucionalizacije i transformacije domova socijalne skrbi i drugih pravnih osoba $\mathrm{u}$ Republici Hrvatskoj 2011.-2016. (2018.)“. Jedan od ciljeva ovog plana je smanjenje ukupnog broja odraslih osoba s invaliditetom na stalnom ili tjednom smještaju u domovima i drugim pravnim osobama koje obavljaju djelatnost socijalne skrbi za 30\%, kao i razvijanje izvaninstitucijskih oblika smještaja i izvaninstitucijskih usluga, razmjerno smanjenju ukupnog broja korisnika na stalnom ili tjednom smještaju. Operativnim planom deinstitucionalizacije i transformacije domova socijalne skrbi i drugih pravnih osoba koje obavljaju djelatnost socijalne skrbi u Republici Hrvatskoj 2014. 2016. određeno je da se ovaj proces odvija kroz tri međusobno uvjetovana ali paralelna dijela a to su:

1) proces deinstitucionalizacije,

2) proces transformacije $i$

3) proces prevencije institucionalizacije i razvoj izvaninstitucionalnih usluga i službi podrške u zajednici.

Navedeni procesi definirani su kroz 5 mjera i 37 pripadajućih aktivnosti.

Neki primjeri provođenja ovog plana su Centar za rehabilitaciju Stančić i Centar za rehabilitaciju Zagreb, kroz osnivanje stambenih zajednica i dnevnih centara (18 stanova i dva dnevna centra). 
Obzirom da je proces deinstitucionalizacije još u tijeku, nemamo dostupnih podataka što se sve do sada ostvarilo. Iz kontakta sa stručnom praksom i obiteljima osoba s intelektualnim teškoćama uviđa se da skrb o starijim osobama s intelektualnim teškoćama još uvijek nije adekvatno i sustavno riješena. Problematika starenja osoba s teškoćama odnosno s invaliditetom još uvijek je nedovoljno zastupljena kako u znanstvenom, tako i u stručnom smislu. Sve češće stručnjaci ukazuju da bi se paralelno sa provođenjem "rane intervencije" trebalo više pažnje usmjeravati i na "kasnu intervenciju".

Starije osobe s intelektualnim teškoćama koje nisu $\mathrm{u}$ institucijama ili u stambenim zajednicama uglavnom žive u starim ekološkim sustavima odnosno u obiteljima sa starim roditeljima. U tom slučaju nije rijetkost da roditelji više nemaju mogućnosti, snage i volje poticati i organizirati odlazak osoba s intelektualnim teškoćama u dnevne centre ili nevladine organizacije koje nude dnevne aktivnosti. Kronične bolesti i narušeno mentalno zdravlje koje prati starost zahvaćaju starije osobe s intelektualnim teškoćama, ali jednako tako i njihove roditelje, te ove obitelji često budu ranjive, potrebite i izolirane. Najviše podrške primaju od članove uže i šire obitelji i susjeda, a sestre i braća kao najbliži srodnici s kojima osobe s intelektualnim teškoćama ostvaruju odnos u najdužem vremenskom razdoblju obično imaju svoju vlastitu obitelj i nemaju vremena ni resursa brinuti o osobama s intelektualnim teškoćama.

U studiji O'Rourke i suradnika (2004) same starije osobe s intelektualnim teškoćama koje žive s obiteljima ili sa skrbnicima izvještavaju da su sretne, ali da su isto tako usamljenije od osoba koje žive u drugim oblicima skrbi. Tome u prilog govore i nalazi Webera i Fritscha (1999; prema O Rourke i sur. 2004), koji navode da su neki od mogućih rizika života starijih osoba s intelektualnim teškoćama u obitelji usamljenost, manjak aktivnosti, „djetinjasti“" stil komunikacije, kao i socijalna izolacija. Ako su obitelji lošeg socioekonomskog statusa, osobama s intelektualnim teškoćama u većoj će mjeri od očekivanoga oslabiti adaptivne vještine te ojačati neprihvatljiva ponašanja (O Rourke i sur. 2004). Stoga je jedan od primarnih zadataka planiranja skrbi o starijim osobama s intelektualnim teškoćama u našoj zemlji pružanje podrške obitelji.

Jedna od tema koja je važna, ali u potpunosti zanemarena u okviru pružanja podrške obiteljima, pripremanje je osoba s intelektualnim teškoćama i njihovih obitelji na neminovne gubitke članova obitelji i prijatelja, kao i podrška u procesu tugovanja (Powell 2000, Duraković i sur. 2007; Vanier 2008; Dumančić, 2013). Važan element u planiranju skrbi za osobe s intelektualnim teškoćama jest pružanje podrške obitelji glede odvajanja, koje se u našoj praksi pokazuje kao veliki uzrok anksioznosti roditelja i samih osoba s intelektualnim teškoćama. Budućnost osoba s intelektualnim teškoćama nužno je planirati za vrijeme života njihovih roditelja, kako bi se imalo dovoljno vremena za pripremu premještaja na neki od daljnjih oblika skrbi.

Briga za budućnost osoba s intelektualnim teškoćama, ali i njihovih sestara i braće bez teškoća, jedan je od najvećih stresora roditeljima. Obzirom na povećani rizik narušenoga mentalnoga zdravlja koju sa godinama razvijaju osobe s intelektualnim teškoćama, obiteljska situacija postaje još složenija. U Hrvatskoj se vrlo mali broj stručnjaka bavi mentalnim zdravljem osoba s intelektualnim teškoćama. U slučajevima koji zahtijevaju hospitalizaciju u psihijatrijske bolnice situacija je vrlo teška, jer stručni kadar nije educirani o specifičnom pristupu osobama s intelektualnim teškoćama. Roditelji se sve više umaraju i iscrpljuju te zaključuju da je jedino rješenje institucionalni smještaj, koji im pruža više osjećaja sigurnosti, naročito ako su stambene zajednice utemeljene kroz projekte nevladinih organizacija, što im pak ulijeva nesigurnost u njihovu održivost.

Nadalje, velike su razlike glede dostupnosti službi podrške u različitim sredinama, pri čemu je dostupnost i raznovrsnost veća u većim gradovima, a najveća je u gradu Zagrebu.

Od velike je važnosti sustavno i zakonski utemeljeno planirati podršku ovim osobama i njihovim obiteljima, kako bi se osobama s intelektualnim teškoćama, ali i njihovim roditeljima, pružila mogućnost "uspješnog" starenja.

\section{ZAKLJUČAK}

Populacija starih osoba s intelektualnim teškoćama u razvijenom svijetu raste. Iako su neki procesi tijekom starenja slični za populaciju osoba sa i bez intelektualnih teškoća, ipak su prisutni i 
neki specifični, povećani rizici kod osoba s teškoćama o kojima je potrebno voditi računa prilikom planiranja podrške.

Razvijene zemlje razvijaju politike u smjeru osiguravanja skrbi o starijim i starim osobama s intelektualnim teškoćama u njihovoj najbližoj okolini kroz podršku kod kuće ili osnivanjem manjih stambenih zajednica. Međutim još uvijek nedostaju dobro razvijeni i sveobuhvatni okviri nacionalnih politika. Dok međunarodna znanstvena zajednica već niz godina ukazuje na čimbenike kvalitetne skrbi o osobama s intelektualnim teškoćama starije dobi, ova problematika, međutim, u Hrvatskoj još uvijek je zanemarena. Pregledom literature ne mogu se naći domaći izvori koji bi se bavili ovom specifičnom temom.
U našoj zemlji kroz vladin i nevladin sektor pokrenute su inicijative podrške starijim osobama s intelektualnim teškoćama kroz osnivanje stambenih zajednica te dnevnih centara. Sustavi podrške, međutim, još uvijek su nedostatni, naročito u pojedinim ekonomski slabijim, ruralnim ili dislociranim mjestima. Veliki broj osoba s intelektualnim teškoćama živi u obiteljima sa svojim roditeljima. Obitelji koja ima člana s intelektualnim teškoćama, u ovoj kasnoj fazi životnog ciklusa neophodna je sustavna podrška, kako bi obitelj održala ravnotežu i kvalitetu života. Kako bi se prevladali brojni i kompleksni izazovi starenja osoba s intelektualnim teškoćama potrebno je razvijati nacionalne, sustavno planirane i razrađene politike i strategije koje bi omogućile dostojanstveno i uspješno starenje ovih osoba, ali i njihovih roditelja. 


\section{LITERATURA}

Ambrosi-Randić, N., Plavšić, M. (2008): Uspješno starenje. Pula: Društvo psihologa Istre, Istarska županija, Sveučilište Jurja Dobrile u Puli.

Brajković, L. (2010): Pokazatelji zadovoljstva životom u trećoj životnoj dobi. Doktorska disertacija. Medicinski fakultet Sveučilišta u Zagrebu.

Bratković, D. (2002): Kvaliteta življenja osoba s umjerenom i težom mentalnom retardacijom u obiteljskim i institucionalnim uvjetima života. Doktorska disertacija. Edukacijsko-rehabilitacijski fakultet Sveučilišta u Zagrebu.

Bratković, D., Rozman, B. (2006): Čimbenici kvalitete življenja osoba s intelektualnim teškoćama. Hrvatska revija za rehabilitacijska istraživanja , 42, 2, 101-112.

Brown, M., Duff, H., Karatzias, T., Horsburgh, D (2011): A review of the literature relating to psychological interventions and people with intellectual disabilities: Issues for research, policy, education and clinical practice. Journal of Intellectual Disabilities, 15, 1, 31-45.

Bigby, C., Webber, R., McKenzie-Green, B., Bowers, B. (2008): A survey of people with intellectual disabilities living in residential aged care facilities in Victoria. Journal of Intellectual Disability Research, 52, 404-414.

Bigby, C. (2010): A Five-Country Comparative Review of Accommodation Support Policies for Older People with Intellectual Disability. Journal of Policy and Practice in Intellectual Disabilities, 7, 1, 3-15.

Bigby, C., Bowers, B., Webber, R. (2011): Planning and decision making about the future care of older group of home residents and transition to residential aged care. Journal of Intellectual Disability Research, 55, 8, 777-789.

Cohen-Sachs, B. (1993): Coping with the stress of aging-creatively. Stress Medicine 9,45-49.

Coyle, C.E, Kramer, J., Mutchler, J.E. (2014): Aging Together: Siblings Carer of Adults with Intellectual and Developmental Disabilities. Journal of Policy and Practice in Intellectual Disabilities, 11, 4, 302-312.

Despot Lučanin, J. (2003): Iskustvo starenja - doprinos teoriji starenja. Jastrebarsko: Naklada Slap.

Došen A. (2011): Studijski dani za Udrugu defektologa grada Zagreba (predavanja, interni materijal).

Dumančić, Z. (2013): Svakodnevni život i proces starenja osoba s višestrukim teškoćama u krugu obitelji. Diplomski rad. Edukacijsko-rehabilitacijski fakultet Sveučilišta u Zagrebu.

Duraković, Z. (2007): Gerijatrija, Medicina starije dobi. Zagreb: C.T.-Poslovne informacije d.o.o,

Galić, S., Tomasović Mrčela, N. (2013): Priručnik iz gerontologije, gerijatrije i psihologije starijih osoba - psihologije starenja. Osijek: Medicinska škola.

Glicken, D., M. (2009): Evidence-based Counseling and Psychotherapy fo an Aging Population, Oxford:Elsevier.

Holland, A.J. (2000) : Aging and learning disability. The British Journal of Psychiatry 176,26-31.

Hubert, J, Hollins, S (2000): Working with elderly carers of people with learning disabilities and planning for the future. Advances in Psychiatric Treatment 6, 41-48.

International Association for the Scientific Study of Intellectual Disabilities (2002): Aging and Intellectual Disabilities, Fact Sheet. Posjećeno 14.08.2014. na mrežnoj stranici International Association for the Scientific Study of Intellectual Disabilities https://iassid.org/pdf/aging-factsheet.pdf

Janicki, M.P., Davidson, P.D., Henderson, C.M., Mc Callion, P., Taets, J.D., Force, L.T., Sulkes, S.B., Frangenberg, E., Ladrigan, P.M., (2002): Health characteristics and health services utilization in odler adults with intellectual disability living in community residences. Journal of Intellectual Disabilities Research 46, 4, 287-298.

Janicki, M.P. (2011): Quality outcomes in group home dementia care for adults with intellectual disabilities. Journal of Intellectual disability Research, 55, 8, 763-776.

Jenkins, R. (2012): The role of nurses in meeting the health care needs of older people with intellectual disabilities: A review of the published literature. Journal of Intellectual Disabilities, 16, 2, 85-95. 
Judge, J., Walley, R., Anderson, B., Young, R. (2010): Activity, Aging, Retirement: The View of Group of Scottish People with Intellectual disabilities. Journal of Policy and Practice in Intellectual Disabilities, 7, 4, 295-301.

Lepan, Ž., Leutar, Z. (2012): Važnost tjelesne aktivnosti u starijoj životnoj dobi. Socijalna ekologija:časopis za ekološku misao i sociologijska istraživanja okoline, 21, 2, 203-224.

Murphy, K., O’Shea, E., Cooney, A., Casey, D., (2007): The Quality of Life of Older People With a Disability in Ireland, National Council on Ageing and Older People. Posjećeno 1.08.2014. na mrežnoj stranici:

http://www.ncaop.ie/publications/research/reports/99_QoL_Disability.pdf

O Rourke, A., Grey, I. M., Fuller, R., McClean, B. (2004): Satisfaction with living arrangements of older adults with intellectual disability. Journal of Learning Disabilities, 8 ,1, 12-29.

Powell, J. (2000): Complicated grieving and the Bevearement- Understanding and treating people experiences loss. New York: Baywood Publishing Company Inc. Amityville.

Schaie. K.W., Willis, S.L. (2000): Psihologija odrasle dobi i starenja. Jastrebarsko: Naklada Slap, Zagreb.

Sačer, K (2014): Doživljaj starenja osobe s intelektualnim teškoćama treće životne dobi. Diplomski rad. Edukacijskorehabilitacijski fakultet Sveučilište u Zagrebu.

Vanier J. (2008): Postati čovjekom. Zagreb: Kršćanska sadašnjost.

Walmsley, J., Johnson, K. (2003): Inclusive research with people with intellectual disabilities: Past, present and futures. London: Jessica Kingsley Publishing.

Wark, S., Hussain, R., Edwards, H. (2013): Rural and Remote Area Service Provision for People Aging with Intellectual Disabilities. Journal of Policy and Practice in Intellectual Disabilities, 10,1, 62-70.

Whitaker, S., Read, S. (2006): The Prevalence of Psychiatric Disorders among People with Intellectual Disabilities: An Analysis of the Literature. Journal of Applied Research in Intellectual Disabilities, 19, 330-345.

World Health Organization (2001): Healthy Aging: Adults with intellectual disabilities. Summative report. Journal of Applied Research in Intellectual Disabilities 14, 256-275.

Zucman, E. (2000): Accompagner les personnes polyhadnicapees. Centre, Paris:Technique National dEtudes et de Recherches sur les Handicaps et les Inadaptations (CTNERHI).

\section{THE CHALLENGES OF AGING IN PERSONS WITH INTELLECTUAL DISABILITIES}

\footnotetext{
Abstract: This article considers some of the challenges met by aging persons with intellectual disabilities that have been pointed out by the international scientific and professional community during the last 20 years. There is a lack of studies and literature on this topic in Croatia, despite the great need to provide adequate support services for elder people with intellectual disabilities.

The population of elderly persons with typical development has been increasing in developed countries, and the life expectancies of people with disabilities in developing countries have grown in parallel with those of persons with typical development. The aging of people with intellectual disabilities is still a rare topic in research and literature. Although some processes during aging are similar in both populations, there are still some specific, increased risks for people with intellectual disabilities that need to be taken into account of when planning support.

Society is challenged by the task of providing optimal support for aging people with intellectual disabilities, which requires the development of specific policies and the implementation of specific strategies that take into account their specific needs.
}

Keywords: aging, people with intellectual disabilities, support services 